\title{
ANALISIS ARIMA DAN WAVELET UNTUK PERAMALAN HARGA CABAI MERAH BESAR DI JAWA TENGAH
}

\author{
Chrisentia Widya Ardianti ${ }^{1}$, Rukun Santoso ${ }^{2}$, Sudarno ${ }^{3}$ \\ 1,2,3 Departemen Statistika FSM Universitas Diponegoro \\ email: chriswidya290397@gmail.com
}

\begin{abstract}
Time series is a type of data collected according to the sequence of times in a certain time span. Time series data can be used as a predictor of future conditions. Analysis of time series data, one of the ARIMA units, is a parametric method that requires an assumption to get valid results. Data stationarity is one of the factors that must be fulfilled. Wavelet is a non-parametric method that is able to represent time and frequency information simultaneously, so that it can analyze non-stationary data. This research presents forecasting the price of red chili in Central Java using ARIMA and wavelet with the approach of the Multiscale Autoregressive (MAR) model. The best model is the one with the smallest MSE value. The results showed that the $\operatorname{ARIMA}(0,1,1)$ model was said to be the best model with MSE $=2252142$. However, because the assumption of normality is not fulfilled, an alternative process is done with wavelet. Wavelet approach results show that the MAR model Haar filter level $(j)=4$ with MSE $=2175906$ is better than Daubechies 4 filter 4 level $(j)=1$ with MSE $=3999669$. Therefore, the Haar wavelet is considered better in the time series analysis.
\end{abstract}

Keyword : ARIMA, wavelet, MAR, forecasting, MSE

\section{PENDAHULUAN}

Komoditas cabai bukanlah bahan pokok bagi masyarakat Indonesia, namun perannya sebagai bumbu pelengkap dalam masakan sangatlah penting. Berdasarkan data tahun 2017, produksi cabai merah besar di Jawa Tengah berada pada urutan kedua terbesar setelah Jawa Barat yaitu sebesar 195.570 ton. Produksi ini memberikan kontribusi sebanyak 16\% terhadap produksi nasional cabai merah besar ${ }^{\{11]}$.

Data harga cabai merah besar merupakan data runtun waktu atau time series. Data time series adalah jenis data yang dikumpulkan menurut urutan waktu dalam rentang waktu tertentu $^{[10]}$. Analisis time series dapat menggunakan beberapa metode, salah satunya adalah metode Box Jenkins atau ARIMA (Autoregressive Integrated Moving Average ${ }^{[2]}$. Analisis data time series merupakan metode parametrik yang membutuhkan suatu asumsi untuk mendapatkan hasil yang valid. Kestasioneran data merupakan salah satu faktor yang harus dipenuhi. Sedangkan data time series banyak yang memiliki sifat nonstasioner, yaitu data tersebut berfluktuasi yang terkadang naik secara tajam atau bahkan turun tiba-tiba secara tajam $^{[3]}$. Oleh karena itu, diperlukan metode alternatif yang bebas dari asumsi, yaitu dengan transformasi wavelet.

Transformasi wavelet adalah metode non parametrik yang mampu merepresentasikan informasi waktu dan frekuensi secara bersamaan, sehingga dapat menganalisis data-data nonstasioner. Suatu data didekomposisi untuk menghasilkan koefisien wavelet dan koefisien skala yang selanjutnya akan digunakan untuk memprediksi data time series pada periode berikutnya $^{[4]}$. Transformasi wavelet membentuk model dari suatu data time series dengan menggunakan metode Maximal Overlap Discrete Wavelet Transform (MODWT) ${ }^{[6]}$. 


\section{TINJAUAN PUSTAKA}

\subsection{Cabai Merah Besar}

Cabai merah besar (Capsicum annuum L.) merupakan tanaman yang tergolong dalam famili terung-terungan (Solanaceae) dengan tinggi pohon sekitar $50 \mathrm{~cm}$. Ukuran cabai sedikit lebih besar jika dibandingkan dengan cabai rawit dengan panjang sekitar 6-10 cm. Cabai mengandung antioksidan yang berfungsi untuk menjaga tubuh dari serangan radikal bebas. Kandungan vitamin $\mathrm{C}$ yang cukup tinggi pada cabai dapat memenuhi kebutuhan harian setiap orang, namun harus di konsumsi secukupnya untuk menghindari nyeri lambung. Kandungan cabai yang berupa lasparaginase dan capsaicin dapat berperan sebagai zat anti kanker ${ }^{[1]}$.

\subsection{Konsep Dasar Time Series}

\subsubsection{Stasioneritas}

Stasioneritas berarti bahwa tidak terjadinya pertumbuhan dan penurunan data. Suatu data dapat dikatakan stasioner apabila pola data tersebut berada pada kesetimbangan disekitar nilai rata-rata yang konstan dan variansi disekitar rata-rata tersebut konstan selama waktu tertentu ${ }^{[5]}$.

Stasioneritas dibagi menjadi dua, dalam variansi dan rata-rata (mean). Jika data tidak stasioner dalam varian maka perlu digunakan transformasi data. Salah satu transformasi yang digunakan adalah dengan transformasi Box-Cox.

Secara visual, dari bentuk plot runtun waktu (time series plot) seringkali dapat diketahui bahwa data tersebut stasioner atau tidak stasioner. Sedangkan secara formal, pengujian stasioneritas dalam rata-rata dari suatu data runtun waktu dapat dilakukan dengan Uji Augmented Dickey Fuller, yakni dengan menguji ada atau tidaknya akar unit (unit root). Jika mengandung unit root, maka data tersebut dikatakan tidak stasioner.

\subsubsection{Autocorrelation Function (ACF)}

Data $\left\{Z_{t}\right\}$ yang stasioner akan mempunyai nilai mean $E\left(Z_{t}\right)=\mu$ dan variansi $\operatorname{var}\left(Z_{t}\right)=$ $E\left(Z_{t}-\mu\right)^{2}=\sigma^{2}$ yang artinya mempunyai nilai-nilai yang konstan, maka kovariansi $\operatorname{cov}\left(Z_{t}, Z_{t+k}\right)$ dapat dituliskan sebagai $\operatorname{cov}\left(Z_{t}, Z_{t+k}\right)=E\left[\left(Z_{t}-\mu\right)\left(Z_{t+k}-\mu\right)\right]=\gamma_{k}$ dengan $\operatorname{var}\left(Z_{t}\right)=\operatorname{var}\left(Z_{t+k}\right)=\gamma_{0}$, sehingga didapatkan autokorelasi pada lag k sebagai $\rho_{k}=\frac{\operatorname{cov}\left(Z_{t}, Z_{t+k}\right)}{\sqrt{\operatorname{var}\left(Z_{t}\right)} \sqrt{\operatorname{var}\left(Z_{t+k}\right)}}=\frac{\gamma_{k}}{\gamma_{0}}[12]$

\subsubsection{Partial Autocorrelation Function (PACF)}

Menurut Soejoeti (1987), himpunan fungsi autokorelasi parsial untuk berbagai lag $\mathrm{k}$ ditulis dengan $\left\{\Phi_{k k} ; k=1,2, \ldots\right\}$. Fungsi ini didefinisikan pada persamaan 2.2

$$
\Phi_{k k}=\frac{\left|P_{k}^{*}\right|}{P_{k}}
$$

dengan $P_{k}$ adalah matriks autokorelasi k x k dan $P_{k}^{*}$ adalah $P_{k}$ dengan kolom terakhir diganti dengan:

$$
\left[\begin{array}{llll}
\rho_{1} & \rho_{2} & \cdots & \rho_{k}
\end{array}\right]^{T}
$$

\subsection{Model Runtun Waktu ARIMA}

Apabila data deret waktu tidak stasioner, model Box-Jenkins dapat diterapkan dengan jalan melakukan differencing (proses pembedaan). Model Box-Jenkins ini disebut model Autoregressive Integrated Moving Average (ARIMA) Box Jenkins. Jika d menyatakan 
banyaknya proses differencing, maka bentuk umum model $\operatorname{ARIMA}(\mathrm{p}, \mathrm{d}, \mathrm{q})$ yang mengkombinasikan model Autoregressive berordo p dengan model Moving Average berordo $\mathrm{q}$ ditulis dengan ARIMA(p,d,q) adalah sebagai berikut

$$
\Phi_{p}(B)(1-B)^{d} Z_{t}=\theta_{q}(B) e_{t}
$$

dengan

$p \quad=\operatorname{order} A R$

$q \quad=\operatorname{order} M A$

$d \quad=$ order pembedaaan (differencing)

$\Phi_{p}(B)=\left(1-\Phi_{1} B-\cdots-\Phi_{p} B^{p}\right)$ merupakan operator $\operatorname{AR}(\mathrm{p})$

$\theta_{q}(B)=\left(1-\theta_{1} B-\cdots-\theta_{p} B^{q}\right)$ merupakan operator MA(q)

\subsection{Prosedur Pemodelan Autoregressive Integrated Moving Average (ARIMA)}

\subsubsection{Identifikasi Model}

Pada tahap identifikasi model berlaku prinsip parsimony, yaitu melibatkan parameter sedikit mungkin ${ }^{[12]}$. Langkah awal dalam identifikasi model adalah membuat plot runtun waktu untuk melihat adanya trend, komponen musiman, outliers, nonstasioneritas dalam variansi, dan lain-lain. Dari plot tersebut, dapat diambil keputusan data akan ditransformasi dan didiferensi atau tidak. Langkah selanjutnya adalah melihat stasioneritas data dari plot ACF (Autocorrelation function) dan PACF (Partial ACF) atau dengan uji unit root.

\subsubsection{Estimasi Parameter Model}

Setelah ditentukan bentuk model yang kira-kira sesuai untuk data, selanjutnya dilakukan estimasi terhadap parameter dalam model. Metode yang digunakan untuk estimasi parameter adalah metode Ordinary Least Square (OLS). Selanjutnya, parameter model diuji layak atau tidaknya dalam model dengan menggunakan uji signifikansi parameter sebagai berikut

$$
t_{\text {hitung }}=\frac{\widehat{\delta}}{S E(\widehat{\delta})}
$$

dengan $\delta$ adalah nilai suatu parameter pada model ARIMA mencakup $\Phi$ dan $\theta$

\subsubsection{Pemeriksaan Diagnostik}

Langkah selanjutnya adalah menguji model tersebut untuk mengetahui bahwa model tersebut cukup baik digunakan untuk peramalan.

1. Uji Independensi Residual

Uji independensi berfungsi untuk mendeteksi kemungkinan terdapat korelasi antar lag dalam residual dari hasil estimasi dengan model yang diamati. Jika residual antar lag menunjukkan adanya korelasi, maka model akan mengalami gangguan autocorrelation. Uji yang dipakai untuk mengukur ada tidaknya autocorrelation salah satunya adalah uji Q Ljung-Box ${ }^{[14]}$.

2. Uji Normalitas Residual

Normalitas residual dapat dilihat secara visual melalui grafik normality probability plot residual, jika residu mengikuti garis diagonal maka residu dapat dikatakan berdistribusi normal. Sedangkan, uji normalitas secara formal dapat menggunakan KolmogorovSmirnov.

\subsubsection{Pemilihan Model Terbaik}

Salah satu cara untuk menguji ketepatan ramalan adalah menggunakan nilai MSE (Mean Square Error) yang merupakan ukuran ketepatan model. 


$$
M S E=\frac{1}{n} \sum_{t=1}^{n} e_{t}^{2}=\frac{1}{n} \sum_{t=1}^{n}\left(Z_{t}-\hat{Z}_{t}\right)^{2}
$$

Model yang terbaik adalah model yang memiliki nilai MSE yang terkecil ${ }^{[5]}$.

\subsubsection{Peramalan}

Tahap identifikasi, estimasi, dan diagnosa memberikan kesimpulan bahwa model yang diperoleh sudah tepat, maka model tersebut dapat digunakan untuk peramalan periode ke depan.

\subsection{Wavelet}

Wavelet adalah sebuah nama untuk gelombang kecil yang naik turun pada periode tertentu $^{[6]}$. Wavelet dibedakan menjadi dua jenis, yaitu wavelet ayah $(\phi)$ dan wavelet ibu $(\psi)$ yang mempunyai sifat: $\int_{-\infty}^{\infty} \phi(\mathrm{t}) \mathrm{dt}=1$ dan $\int_{-\infty}^{\infty} \psi(\mathrm{t}) \mathrm{dt}=0$. Jika tidak menyebutkan gendernya, maka kata wavelet menunjuk pada wavelet ibu. Wavelet ayah kadang kala disebut juga sebagai fungsi skala. Wavelet memiliki keturunan, yaitu bentuk translasi dan dilatasi dari wavelet ayah dan wavelet ibu yaitu :

$\phi_{j, k}(t)=\left(2^{j}\right)^{\frac{1}{2}} \phi\left(2^{j} t-k\right)$
$\psi_{j, k}(t)=\left(2^{j}\right)^{\frac{1}{2}} \psi\left(2^{j} t-k\right)$

\subsubsection{Transformasi Wavelet}

Fungsi wavelet dapat membentuk basis dalam ruang $\mathrm{L}^{2} \mathrm{R}$ dengan $\mathrm{L}^{2} \mathrm{R}=$ $\left\{f \mid \int_{-\infty}^{\infty} f^{2}(t) d t<\infty\right\}$. Sebagai akibatnya setiap $f \in \mathrm{L}^{2} \mathrm{R}$ dapat dinyatakan sebagai kombinasi linier suatu basis yang dibangun oleh wavelet ${ }^{[13]}$

$$
\begin{array}{cc}
f(t)=\sum_{k \in Z} c_{J, k} \phi_{J, k}(t)+\sum_{j<J} \sum_{k \in Z} d_{j, k} \psi_{j, k}(t) \\
\text { dengan } \quad c_{J, k}=\left\langle f, \phi_{J, k}\right\rangle=\int f(t) \phi_{J, k}(t) d t \\
d_{j, k}=\left\langle f, \Psi_{j, k}\right\rangle=\int f(t) \Psi_{j, k}(t) d t
\end{array}
$$

Fungsi f menghasilkan bentuk deret tak hingga, namun fungsi f dapat didekati dengan baik mneggunakan jumlahan terbatas sampai dengan indeks $\mathrm{J}$, dengan $\mathrm{J}$ besar, maka dapat dinyatakan sebagai jumlahan komponen skala $S$ dan komponen detail D

$$
\begin{aligned}
f_{J}(t) & =\sum_{k \in Z} c_{J, k} \phi_{J, k}(t)+\sum_{k \in Z} d_{J-1, k} \psi_{J-1, k}(t)+\sum_{k \in Z} d_{J-2, k} \psi_{J-2, k}(t)+\ldots+\sum_{k \in Z} d_{1, k} \psi_{1, k}(t) \\
& =S_{J}+D_{J-1}+D_{J-2}+\cdots+D_{1}
\end{aligned}
$$

\subsubsection{Transformasi Wavelet Diskrit}

DWT dari sebuah deret waktu $\mathrm{X}$, dengan panjang $\mathrm{N}$ adalah sebuah transformasi linier, dengan pembentukan W dari koefisien DWT per-level. Perkalian matriks filter atas X adalah sebagai berikut:

$$
\mathcal{W} \mathrm{X}=\left[\begin{array}{c}
\mathcal{W}_{1} \\
\mathcal{W}_{2} \\
\vdots \\
\mathcal{W}_{J} \\
\mathcal{V}_{J}
\end{array}\right] \mathrm{X}=\left[\begin{array}{c}
\mathcal{W}_{1} \mathrm{X} \\
\mathcal{W}_{2} \mathrm{X} \\
\vdots \\
\mathcal{W}_{J} \mathrm{X} \\
\mathcal{V}_{J} \mathrm{X}
\end{array}\right]=\left[\begin{array}{c}
\mathrm{W}_{1} \\
\mathrm{~W}_{2} \\
\vdots \\
\mathrm{W}_{\mathrm{J}} \\
\mathrm{V}_{\mathrm{J}}
\end{array}\right]=\mathrm{W}
$$

Suatu filter wavelet DWT harus memenuhi tiga sifat dasar berikut:

$\sum_{i=0}^{L-1} h_{l}=0, \sum_{i=0}^{L-1} h_{l}^{2}=1, \sum_{l=0}^{L-1} h_{l} h_{l+2 n}=\sum_{l=-\infty}^{\infty} h_{l} h_{l+2 n}=0$

Filter skala diasumsikan memenuhi kondisi berikut:

$\sum_{l=0}^{L-1} g_{l}=\sqrt{2}, \sum_{l=0}^{L-1} g_{l}^{2}=1, \sum_{l=-\infty}^{\infty} g_{l} g_{l+2 n}=0$ dan $\sum_{l=-\infty}^{\infty} g_{l} h_{l+2 n^{\prime}}=0$

Syarat yang harus dipenuhi untuk memenuhi sifat-sifat tersebut adalah panjang filter $L$ bernilai genap $^{[6]}$. 


\subsubsection{Filter Wavelet Haar dan Daubechies 4}

\section{Filter Haar}

Koefisien filter wavelet $h_{0}=\frac{1}{\sqrt{2}}, h_{1}=-\frac{1}{\sqrt{2}}$

Koefisien skala $g_{0}=\frac{1}{\sqrt{2}}, g_{1}=\frac{1}{\sqrt{2}}$

\section{Filter Daubechies 4}

koefisien filter wavelet $h_{0}=\frac{1-\sqrt{3}}{4 \sqrt{2}}, h_{1}=\frac{-3+\sqrt{3}}{4 \sqrt{2}}, h_{2}=\frac{3+\sqrt{3}}{4 \sqrt{2}}, h_{3}=\frac{-1-\sqrt{3}}{4 \sqrt{2}}$

koefisien skala $g_{0}=\frac{1+\sqrt{3}}{4 \sqrt{2}}, g_{1}=\frac{3+\sqrt{3}}{4 \sqrt{2}}, g_{2}=\frac{3-\sqrt{3}}{4 \sqrt{2}}, g_{3}=\frac{1-\sqrt{3}}{4 \sqrt{2}}$

\subsubsection{Algoritma Piramida}

1. Algoritma level pertama

$$
\begin{aligned}
& \mathcal{P}_{1} \mathrm{X}=\left[\begin{array}{l}
\mathcal{W}_{1} \\
\mathcal{V}_{1}
\end{array}\right] \mathrm{X}=\left[\begin{array}{l}
\mathcal{W}_{1} \mathrm{X} \\
\mathcal{V}_{1} \mathrm{X}
\end{array}\right]=\left[\begin{array}{l}
\mathrm{W}_{1} \\
\mathrm{~V}_{1}
\end{array}\right] \\
& \mathrm{X}=\mathcal{P}_{1}^{T}\left[\begin{array}{l}
\mathrm{W}_{1} \\
\mathrm{~V}_{1}
\end{array}\right] \\
& \mathrm{X}=\left[\begin{array}{ll}
\mathcal{W}_{1}^{\tau} & \mathcal{V}_{1}^{\tau}
\end{array}\right]\left[\begin{array}{l}
\mathrm{W}_{1} \\
\mathrm{~V}_{1}
\end{array}\right] \\
& \mathrm{X}=\mathcal{W}_{1}^{\tau} \mathrm{W}_{1}+\mathcal{V}_{1}^{\tau} \mathrm{V}_{1} \\
& \mathrm{X}=D_{1}+S_{1}
\end{aligned}
$$

2. Algoritma level kedua

$$
\mathcal{P}_{2} \mathrm{~V}_{1}=\left[\begin{array}{l}
\mathcal{B}_{2} \\
\mathcal{A}_{2}
\end{array}\right] \mathrm{V}_{1}=\left[\begin{array}{l}
\mathrm{W}_{2} \\
\mathrm{~V}_{2}
\end{array}\right]
$$

Misalkan $\mathcal{B}_{1}=\mathcal{W}_{1}$ dan $\mathcal{A}_{1}=\mathcal{V}_{1}$, maka $\mathcal{W}_{2}=\mathcal{B}_{2} \mathcal{V}_{1}=\mathcal{B}_{2} \mathcal{A}_{1}$ dan $\mathcal{V}_{2}=\mathcal{A}_{2} \mathcal{V}_{1}=$ $\mathcal{A}_{2} \mathcal{A}_{1}$, sehingga

$\mathrm{X}=\mathcal{W}_{1}^{\tau} \mathrm{W}_{1}+\mathcal{V}_{1}^{\tau} \mathcal{B}_{2}^{\tau} \mathrm{W}_{2}+\mathcal{V}_{1}^{\tau} \mathcal{A}_{2}^{\tau} \mathrm{V}_{2}$

atau

$\mathrm{X}=\mathcal{B}_{1}^{\tau} \mathrm{W}_{1}+\mathcal{A}_{1}^{\tau} \mathcal{B}_{2}^{\tau} \mathrm{W}_{2}+\mathcal{A}_{1}^{\tau} \mathcal{A}_{2}^{\tau} \mathrm{V}_{2}$

$\mathrm{X}=D_{1}+S_{1}$

$\mathrm{X}=D_{1}+\left(D_{2}+S_{2}\right)$

3. Algoritma level ke $\mathrm{j}$

$$
\begin{aligned}
& \mathrm{X} \\
& =\mathcal{W}^{T} \mathrm{~W}=\sum_{j=1}^{J 0} \mathcal{W}_{j}^{\tau} \mathrm{W}_{j}+\mathcal{V}_{J 0}^{\tau} \mathrm{V}_{J 0} \\
& \text { atau } \\
& \begin{aligned}
\mathrm{X} & =D_{1}+S_{1} \\
& =D_{1}+\left(D_{2}+S_{2}\right) \\
& =D_{1}+D_{2}+\left(D_{3}+S_{3}\right) \\
& =D_{1}+D_{2}+\cdots+D_{\left(J_{0}\right)-1}+\left(D_{J_{0}}+S_{J_{0}}\right) \\
\mathrm{X} & =\sum_{j=1}^{J 0} D_{j}+S_{J 0}
\end{aligned}
\end{aligned}
$$

\subsubsection{Maximal Overlap DWT}

Maximal Overlap Discrete Wavelet Transform (MODWT) adalah bentuk modifikasi dan transformasi wavelet diskrit. MODWT memiliki kelebihan dapat digunakan untuk setiap ukuran sampel $\mathrm{N}^{[6]}$. Filter wavelet dan filter skala pada MODWT dapat ditentukan berdasarkan filter wavelet dan filter skala pada DWT.

Sehingga syarat suatu filter wavelet MODWT harus memenuhi persamaan berikut 


$$
\sum_{i=0}^{L-1} h_{l}=0, \sum_{i=0}^{L-1} h_{l}^{2}=\frac{1}{2}, \sum_{l=0}^{L-1} h_{l} h_{l+2 n}=0
$$

Filter skala harus memenuhi persamaan berikut:

$$
\sum_{l=0}^{L-1} g_{l}=1, \sum_{l=0}^{L-1} g_{l}^{2}=\frac{1}{2}, \sum_{l=0}^{L-1} g_{l} g_{l+2 n}=0
$$

dengan $\mathrm{n}=1,2, \ldots,\left(\frac{L}{2}-1\right)$

Masing-masing MODWT memiliki lebar $L_{j}=\left(2^{j}-1\right)(L-1)+1$

\subsubsection{Multiscale Autoregressive (MAR)}

Pada MODWT koefisien wavelet pada setiap level selalu sama sehingga lebih sesuai untuk pemodelan pada time series dibandingkan dengan DWT. Prediksi data time series satu langkah ke depan dimodelkan secara linear berdasarkan koefisien wavelet hasil dekomposisi pada waktu-waktu sebelumnya. Sebuah proses autoregresif dengan p order atau AR(p), jika menggunakan dekomposisi koefisien wavelet, prediksi AR akan menjadi model multiskala autoregressive (MAR) seperti berikut ${ }^{[9]}$ :

$$
\hat{Z}_{t+1}=\sum_{j=1}^{J} \sum_{k=1}^{A_{j}} \hat{a}_{j, k} w_{j, t-2^{j}(k-1)}+\sum_{k=1}^{A_{J+1}} \hat{a}_{J+1, k} v_{J, t-2^{J}(k-1)}
$$

Input dan prosedur peramalan data ke $Z_{t+1}$ dengan model wavelet Haar dapat diilustrasikan seperti berikut. Misal terdapat data sebanyak data 17 data. Dalam melakukan peramalan data ke-18, dengan model wavelet orde 2, maka variabel input yang digunakan adalah koefisien wavelet level 1 pada $\mathrm{t}=17$ dan $\mathrm{t}=15$, koefisien wavelet level 2 pada $\mathrm{t}=17$ dan $\mathrm{t}=13$, koefisien wavelet level 3 pada $\mathrm{t}=17$ dan $\mathrm{t}=9$, koefisien wavelet level 4 pada $\mathrm{t}=17 \mathrm{dan} \mathrm{t}=4$, dan koefisien smooth level 4 pada $\mathrm{t}=17 \mathrm{dan} \mathrm{t}=1$. Sehingga input yang kedua pada tiap-tiap level adalah $t-2^{j}$.

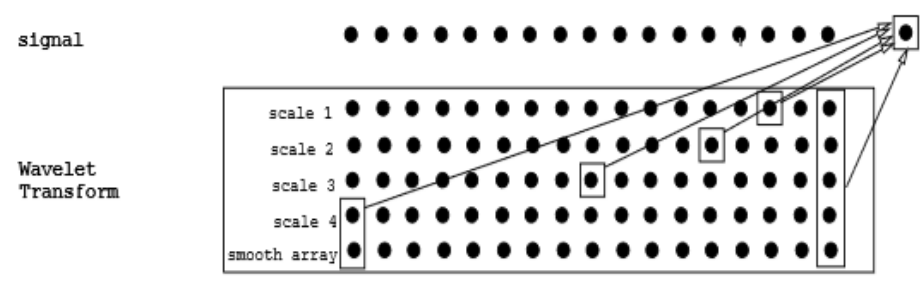

Gambar 1. Ilustrasi Pemodelan wavelet Haar untuk $\mathrm{J}=4, \boldsymbol{A}_{\boldsymbol{j}}=2, \mathrm{~N}=17$

Sebagai contoh, $\mathrm{J}=4$, dan $\mathrm{A}_{\mathrm{j}}=2$, maka rumus MAR dengan metode wavelet Haar akan menjadi seperti berikut:

$$
\begin{aligned}
\hat{Z}_{t+1}= & \hat{a}_{1,1} w_{1, t}+\hat{a}_{1,2} w_{1, t-2}+\hat{a}_{2,1} w_{2, t}+\hat{a}_{2,2} w_{2, t-4}+\hat{a}_{3,1} w_{3, t}+\hat{a}_{3,2} w_{3, t-8}+\hat{a}_{4,1} w_{4, t} \\
& +\hat{a}_{4,2} w_{4, t-16}+\hat{a}_{5,1} v_{4, t}+\hat{a}_{5,2} v_{4, t-16}
\end{aligned}
$$

Pemilihan koefisien-koefisien ini menjadi patokan dalam membuat sintaks pada software R. dari level 1 didapat $w_{1, t}$, yang selanjutnya dinamai sebagai variabel $\mathrm{X}_{1}$ dan koefisien $\hat{a}_{1,1}$ selanjutnya dinamai $\hat{\beta}_{1}$. Dari level 1 juga didapat $w_{1, t-2}$ yang selanjutnya dinamai sebagai variabel $\mathrm{X}_{2}$ dan koefisien $\hat{a}_{1,2}$ selanjutnya dinamai $\hat{\beta}_{2}$. Begitu seterusnya, samapi terakhir dari level 4 didapat $v_{4, t-16}$ yang selanjutnya dinamai sebagai variabel $\mathrm{X}_{10}$ dan koefisien $\hat{a}_{5,2}$ selanjutnya dinamai $\hat{\beta}_{10}$. Maka model MAR menjadi:

$$
\hat{Z}_{t+1}=\hat{\beta}_{1} \mathrm{X}_{1}+\hat{\beta}_{2} \mathrm{X}_{2}+\hat{\beta}_{3} \mathrm{X}_{3}+\hat{\beta}_{4} \mathrm{X}_{4}+\hat{\beta}_{5} \mathrm{X}_{5}+\hat{\beta}_{6} \mathrm{X}_{6}+\hat{\beta}_{7} \mathrm{X}_{7}+\hat{\beta}_{8} \mathrm{X}_{8}+\hat{\beta}_{9} \mathrm{X}_{9}+\hat{\beta}_{10} \mathrm{X}_{10}
$$

Sedangkan jika dengan metode Daubechies 4 (db4), dengan $J=3$ dan $A_{j}=2$, maka ilustrasi pemodelannya akan menjadi seperti berikut 


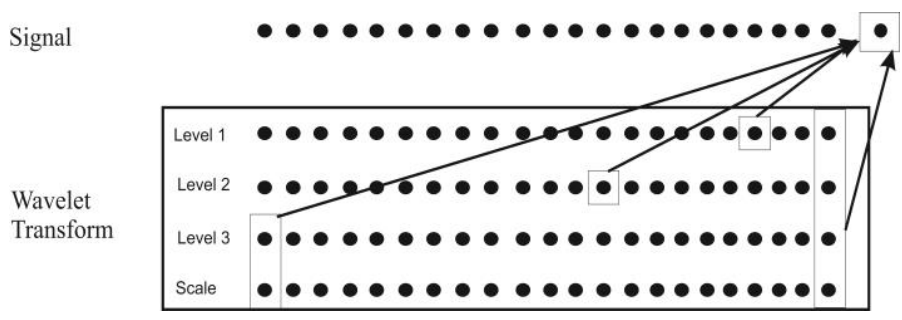

Gambar 2. Ilustrasi Pemodelan wavelet db4 untuk $\mathrm{J}=3, \mathbf{A}_{\mathbf{j}}=2, \mathrm{~N}=22$

Rumus MAR dengan metode wavelet Daubechies 4 akan menjadi seperti berikut:

$$
\hat{Z}_{t+1}=w_{1, t}+w_{1, t-4}+w_{2, t}+w_{2, t-10}+w_{3, t}+w_{3, t-22}+v_{4, t}+v_{4, t-22}
$$

\section{METODOLOGI PENELITIAN}

Data yang digunakan dalam penelitian ini adalah data sekunder, yaitu data harga cabai merah besar harian di Jawa Tengah yang diperoleh dari https://hargapangan.id/ sebanyak 474 data. Variabel data yang digunakan dalam penelitian ini adalah data harga cabai merah besar harian di Jawa Tengah selama periode 2 Januari 2018 sampai 29 November 2019, dengan data training adalah data pada periode 2 Januari 2018 - 31 Oktober 2019 sebanyak 453 data, dan data testing adalah data pada periode November 2019 sebanyak 21 data.

Data dalam penelitian ini diolah dengan menggunakan software Minitab 17, Eviews-9, dan $R$. Adapun langkah-langkah analisis dalam menyelesaikan penelitian ini adalah sebagai berikut:

1. Membagi data menjadi dua bagian, yaitu data training dan data testing.

2. Data training yaitu data harga cabai merah besar di Jawa Tengah periode 2 Januari 2018 - 31 Oktober 2019 sebanyak 453 data digunakan untuk pendugaan dan pencarian model terbaik.

3. Data testing yaitu data harga cabai merah besar di Jawa Tengah periode November 2019 sebanyak 21 data digunakan sebagai data validasi hasil peramalan.

4. Menguji asumsi stasioneritas data training dalam varian dan mean.

5. Jika belum stasioner dalam varian, dilakukan proses transformasi menggunakan BoxCox. Jika belum stasioner dalam mean, dilakukan proses differensi, kemudian dilakukan kembali uji stasioneritas.

6. Melakukan identifikasi model dengan mengamati plot ACF dan PACF.

7. Melakukan estimasi parameter terhadap model-model yang terbentuk serta menguji signifikansi parameternya.

8. Melakukan uji independensi dengan uji Ljung-Box dan uji normalitas residual dengan melihat secara visual pada grafik normal probability plot atau secara formal dengan uji Kolmogorov Smirnov pada tahap diagnostik parameter pada model yang terbentuk.

9. Melakukan peramalan terhadap model terbaik dengan mencari model yang memiliki nilai MSE terkecil.

10. Memodelkan data menggunakan metode dekomposisi Maximal Overlap Discrete Wavelet Transform (MODWT) dengan pendekatan MAR filter Haar dan Daubechies 4 pada program $\mathrm{R}$ dengan paket wavelets.

11. Mencari MSE terkecil dari tiap model MAR yang terbentuk pada filter Haar dan Daubechies 4 supaya didapat model terbaik. 
12. Membandingkan MSE terkecil yang didapat pada proses ARIMA dan wavelet dengan data testing untuk mengetahui metode yang lebih baik.

\section{ANALISIS DAN PEMBAHASAN}

\subsection{Metode ARIMA}

\subsubsection{Identifikasi Model}

a. Plot Harga Cabai Merah Besar di Jawa Tengah

Plot data runtun waktu digunakan untuk melihat kestasioneran data dalam varian dan mean. Plot runtun waktu dari data harga cabai merah besar ditunjukkan sebagai berikut:

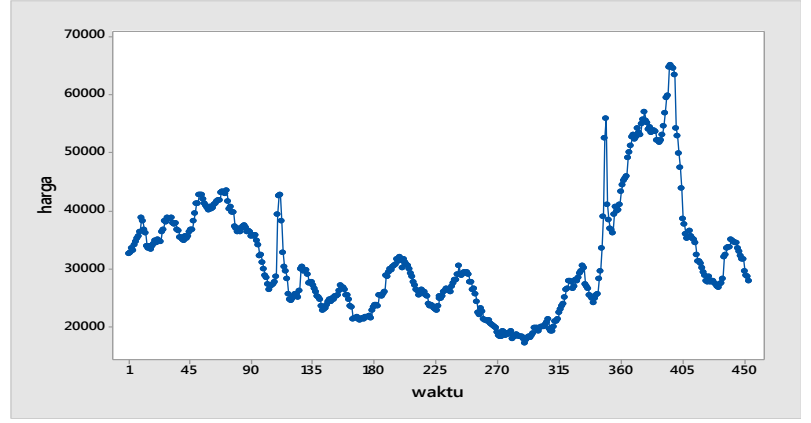

Gambar 3. Plot Data Harga Cabai Merah Besar di Jawa Tengah

Dari plot data di atas, terlihat bahwa data belum stasioner varian dan mean (masih terdapat unsur trend), sehingga data tersebut harus distasionerkan.

b. Stasioneritas dalam Varian dan Mean

Dari plot Box-Cox didapat nilai taksiran lambda adalah sebesar $-0,43$. Nilai tersebut dikatakan mendekati $-0,50$ dan berada dalam batas interval kepercayaan $95 \%$, dengan batas bawah $-0,69$ dan batas atas $-0,13$. Maka data tersebut belum stastioner dalam varian dan harus ditransformasi menggunakan transformasi $\frac{1}{\sqrt{z_{t}}}$.

Pada output Augmented Dickey Fuller Unit Root Test, didapat nilai $P$-value $=0,1373>\alpha=$ 0,05 yang berarti $H_{0}$ diterima. Maka dapat disimpulkan bahwa data tersebut terdapat akar unit atau tidak stasioner.

c. Transformasi dan Differencing Data

Dari hasil transformasi Box-Cox didapat nilai taksiran lambda adalah sebesar 0,85. Nilai tersebut dikatakan mendekati 1 dan berada dalam batas interval kepercayaan 95\%, dengan batas bawah 0,25 dan batas atas 1,43. Maka data tersebut sudah stastioner dalam varian. Selanjutnya, dilakukan differencing 1 terhadap data transformasi, sehingga menghasilkan plot data sebagai berikut:

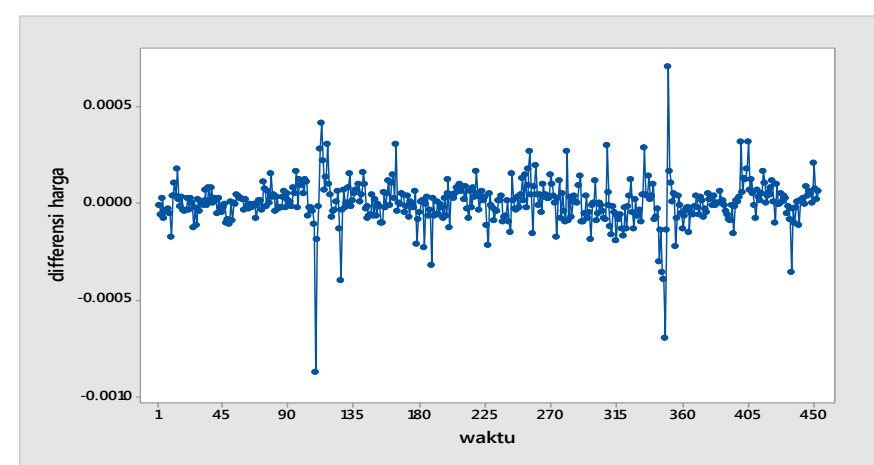

Gambar 4. Plot Data Transformasi dengan Differencing 1 
Dari plot data terlihat bahwa pola data yang terbentuk secara umum mengindikasikan bahwa data telah stasioner setelah dilakukan differencing 1.

Pada output Augmented Dickey Fuller Unit Root Test, didapat nilai $P$-value $=0,0000<\alpha=$ 0,05 yang berarti $H_{0}$ ditolak. Maka dapat disimpulkan bahwa data tersebut tidak terdapat akar unit atau stasioner

d. Identifikasi Model

Berdasarkan correlogram ACF dan PACF data mengalami cut off pada lag pertama, hal ini menunjukkan adanya proses AR(1) dan MA(1). Maka diperoleh model ARIMA sementara yaitu ARIMA(1,1,1). Kemudian dilakukan overfitting disekitar model sebagai salah satu langkah untuk membandingkan model satu dengan model lainnya demi mendapatkan model yang memberikan hasil prediksi yang dianggap baik. Model lainnya yang mungkin dibentuk adalah $\operatorname{ARIMA}(1,1,0), \operatorname{ARIMA}(0,1,1), \operatorname{ARIMA}(2,1,1), \operatorname{ARIMA}(1,1,2), \operatorname{ARIMA}(2,1,0)$, $\operatorname{ARIMA}(2,1,2)$, dan $\operatorname{ARIMA}(0,1,2)$.

\subsubsection{Estimasi Parameter Model}

\section{a. $\operatorname{ARIMA}(2,1,2)$}

$$
\begin{aligned}
& Z_{t}=-0,5341 Z_{t-1}+0,1372 Z_{t-2}-0,8981 \theta_{1}-0,1097 \theta_{2}+e_{t} \\
& \begin{array}{llll}
(0,363) & (0,321) & (0,126) & (0,629)
\end{array}
\end{aligned}
$$

b. ARIMA $(2,1,1)$

$$
\begin{gathered}
Z_{t}=1,1849 Z_{t-1}-0,3238 Z_{t-2}+0,8372 \theta_{1}+e_{t} \\
(0,000) \\
(0,000)
\end{gathered}
$$

c. $\operatorname{ARIMA}(\mathbf{2 , 1 , 0})$

$$
Z_{t}=0,3623 Z_{t-1}-0,0713 Z_{t-2}+e_{t}
$$

$$
(0,000) \quad(0,131)
$$

\section{d. ARIMA $(1,1,2)$}

(Model tidak dapat diestimasi)

e. $\operatorname{ARIMA}(\mathbf{1 , 1 , 1 )}$

$$
Z_{t}=0,1456 Z_{t-1}-0,2184 \theta_{1}+e_{t}
$$

$$
(0,272) \quad(0,095)
$$

\section{f. $\operatorname{ARIMA}(1,1,0)$}

$$
Z_{t}=0,3382 Z_{t-1}+e_{t}
$$

g. $\operatorname{ARIMA}(0,1,2)$

$$
\begin{gathered}
Z_{t}=-0,3632 \theta_{1}-0,049 \theta_{2}+e_{t} \\
(0,000) \\
(0,3)
\end{gathered}
$$

\section{h. ARIMA (0,1,1)}

$$
Z_{t}=-0,3479 \theta_{1}+e_{t}
$$

$$
(0,000)
$$

Berdasarkan model-model tersebut, model $\operatorname{ARIMA}(2,1,1)$, $\operatorname{ARIMA}(1,1,0)$, dan $\operatorname{ARIMA}(0,1,1)$ memiliki parameter yang signifikan. Selanjutnya, semua model dilakukan pemeriksaan pada residualnya sudah white noise atau belum, yaitu residual harus independen (tidak berkorelasi) dan berdistribusi normal. 


\subsubsection{Pemeriksaan Diagnostik}

Tabel 1. Pemeriksaan Diagnostik

\begin{tabular}{|lll|}
\hline Model & Uji Independensi Residual & Uji Normalitas Residual \\
\hline ARIMA $(2,1,2)$ & Independen & Tidak terpenuhi \\
ARIMA $(2,1,1)$ & Independen & Tidak terpenuhi \\
ARIMA $(2,1,0)$ & Independen & Tidak terpenuhi \\
ARIMA $(1,1,2)$ & Error & \\
ARIMA $(1,1,1)$ & Independen & Tidak terpenuhi \\
ARIMA $(1,1,0)$ & Independen & Tidak terpenuhi \\
ARIMA $(0,1,2)$ & Independen & Tidak terpenuhi \\
ARIMA $(0,1,1)$ & Independen & Tidak terpenuhi \\
\hline
\end{tabular}

\subsubsection{Pemilihan Model Terbaik}

Berikut adalah tabel pemilihan model terbaik:

Tabel 2. Pemilihan Model Terbaik

\begin{tabular}{|lllll|}
\hline Model & Estimasi & Uji Independensi & Uji Normalitas & MSE \\
& Parameter & Residual & Residual & \\
\hline ARIMA(2,1,2) & Tidak Signifikan & Independen & Tidak terpenuhi & 2260483 \\
ARIMA(2,1,1) & Signifikan & Independen & Tidak terpenuhi & 2255768 \\
ARIMA $(2,1,0)$ & Tidak Signifikan & Independen & Tidak terpenuhi & 2252470 \\
ARIMA $(1,1,2)$ & Error & & & \\
ARIMA $(1,1,1)$ & Tidak Signifikan & Independen & Tidak terpenuhi & 2251587 \\
& & & & \\
ARIMA $(1,1,0)$ & Signifikan & Independen & Tidak terpenuhi & 2258942 \\
ARIMA $(0,1,2)$ & Tidak Signifikan & Independen & Tidak terpenuhi & 2251891 \\
& & & & \\
ARIMA $(0,1,1)$ & Signifikan & Independen & Tidak terpenuhi & 2252142 \\
\hline
\end{tabular}

Berdasarkan hasil pengujian signifikansi parameter, uji independensi residual, dan uji asumsi normalitas residual, dapat dikatakan bahwa model terbaik dan peramalan akan kurang tepat jika dilakukan karena syarat normalitas residual pada setiap model tidak terpenuhi. Namun, jika syarat normalitas diabaikan, model ARIMA $(0,1,1)$ dapat dikatakan sebagai model terbaik, karena memiliki nilai MSE terkecil. Sebagai alternatif, diperlukan analisis nonparametrik untuk membantu penyelesaian penelitian yang tidak membutuhkan asumsi.

\subsection{Model Runtun Waktu dengan Pendekatan Wavelet}

\subsubsection{Model Pendekatan dengan Filter Haar}

a. Filter Haar dengan $j=1$

Model awal yang terbentuk dengan memasukan empat variabel adalah:

$\hat{Z}_{t+1}=1,80185 \mathrm{X}_{1}+0,01101 \mathrm{X}_{2}+0,92206 \mathrm{X}_{3}+0,07621 \mathrm{X}_{4}$

$$
\begin{array}{llll}
\left(<2 \times 10^{-16}\right) & (0,360) \quad\left(<2 \times 10^{-16}\right) \quad(0,129)
\end{array}
$$

Model yang terbentuk dari dua variabel yang signifikan adalah

$\hat{Z}_{t+1}=1.675910 \mathrm{X}_{1}+0.998205 \mathrm{X}_{3}$

$$
\left(<2 \times 10^{-16}\right) \quad\left(<2 \times 10^{-16}\right)
$$


Hasil prediksi MAR filter Haar dengan $j=1$ bila diplotkan dengan data asli akan tampak seperti Gambar 5:

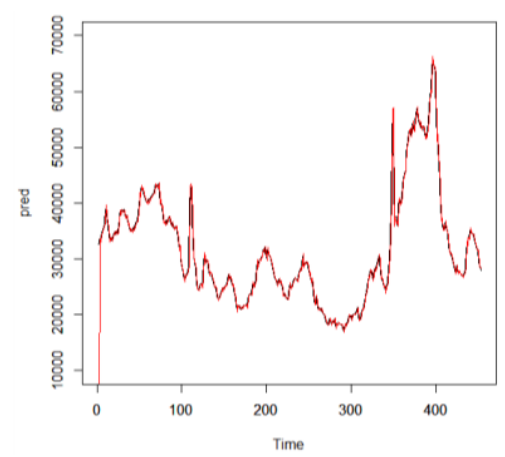

Gambar 5. Plot Time Series Data Asli dan Prediksi MAR Filter Haar dengan $\mathrm{j}=1$

b. Filter Haar dengan $j=2$

Model awal yang terbentuk dengan memasukan enam variabel adalah:

$$
\begin{aligned}
\hat{Z}_{t+1}= & 1,804609 \mathrm{X}_{1}+0,126985 \mathrm{X}_{2}+0.844913 \mathrm{X}_{3}-0.041455 \mathrm{X}_{4} \\
& \left(<2 \times 10^{-16}\right) \quad(0,372) \quad\left(1,4 \times 10^{-14}\right) \quad(0,633) \\
& +0.994368 \mathrm{X}_{5}+0.003976 \mathrm{X}_{6} \\
& \left(<2 \times 10^{-16}\right) \quad(0,920)
\end{aligned}
$$

Model yang terbentuk dari tiga variabel yang signifikan adalah $\hat{Z}_{t+1}=1,754947 \mathrm{X}_{1}+0,908135 \mathrm{X}_{3}+0,998264 \mathrm{X}_{5}$

$$
\left(<2 \times 10^{-16}\right) \quad\left(<2 \times 10^{-16}\right) \quad\left(<2 \times 10^{-16}\right)
$$

Hasil prediksi MAR filter Haar dengan $j=2$ bila diplotkan dengan data asli akan tampak seperti Gambar 6:

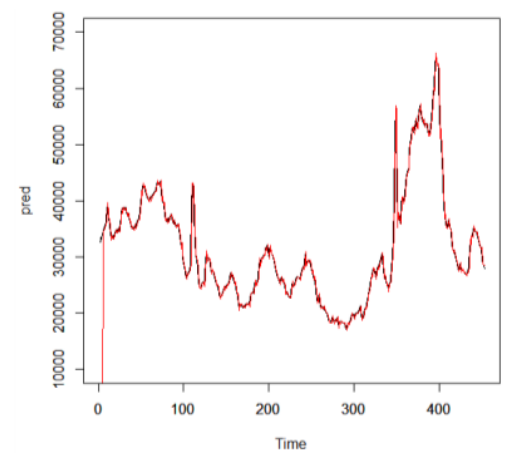

Gambar 6. Plot Time Series Data Asli dan Prediksi MAR Filter Haar dengan j = 2

c. Filter Haar dengan $\boldsymbol{j}=\mathbf{3}$

Model awal yang terbentuk dengan memasukan delapan variabel adalah:

$$
\begin{aligned}
& \hat{Z}_{t+1}=1,794711 \mathrm{X}_{1}+0,134671 \mathrm{X}_{2}+0,842015 \mathrm{X}_{3}+0,021408 \mathrm{X}_{4} \\
& \begin{array}{llll}
\left(<2 \times 10^{-16}\right) & (0,345) \quad\left(2,22 \times 10^{-14}\right) \quad(0,831)
\end{array} \\
& +1,009697 \mathrm{X}_{5}+0,003091 \mathrm{X}_{6}+0,962345 \mathrm{X}_{7}+0,036186 \mathrm{X}_{8} \\
& \begin{array}{lll}
\left(<2 \times 10^{-16}\right) & (0,957) \quad\left(<2 \times 10^{-16}\right) \quad(0,170)
\end{array}
\end{aligned}
$$

Model yang terbentuk dari empat variabel yang signifikan adalah $\hat{Z}_{t+1}=1,749313 \mathrm{X}_{1}+0,918890 \mathrm{X}_{3}+0,985739 \mathrm{X}_{5}+0,998175 \mathrm{X}_{7}$

$$
\left(<2 \times 10^{-16}\right) \quad\left(<2 \times 10^{-16}\right) \quad\left(<2 \times 10^{-16}\right) \quad\left(<2 \times 10^{-16}\right)
$$

Hasil prediksi MAR filter Haar dengan $j=3$ bila diplotkan dengan data asli akan tampak seperti Gambar 7: 


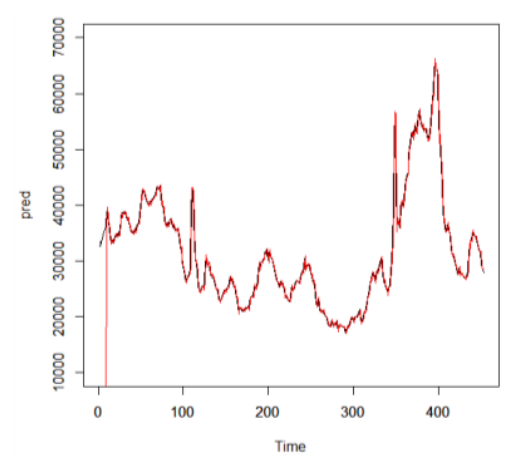

Gambar 7. Plot Time Series Data Asli dan Prediksi MAR Filter Haar dengan $j=3$

\section{d. Filter Haar dengan $j=4$}

Model awal yang terbentuk dengan memasukan sepuluh variabel adalah:

$$
\begin{aligned}
& \hat{Z}_{t+1}=1,78664 \mathrm{X}_{1}+0,12561 \mathrm{X}_{2}+0,83366 \mathrm{X}_{3}+0,01532 \mathrm{X}_{4}+1,00808 \mathrm{X}_{5} \\
& \begin{array}{lllll}
\left(<2 \times 10^{-16}\right) & (0,3828) & \left(5,93 \times 10^{-14}\right) & (0,8793) \quad\left(<2 \times 10^{-16}\right)
\end{array} \\
& -0,03919 \mathrm{X}_{6}+0,90738 \mathrm{X}_{7}-0,01295 \mathrm{X}_{8}+1,02972 \mathrm{X}_{9}-0,03151 \mathrm{X}_{10} \\
& \begin{array}{lllll}
(0,5553) \quad\left(<2 \times 10^{-16}\right) & (0,7415) \quad\left(<2 \times 10^{-16}\right) \quad(0,0832)
\end{array}
\end{aligned}
$$

Model yang terbentuk dari lima variabel yang signifikan adalah

$$
\begin{aligned}
\hat{Z}_{t+1}= & 1,752498 \mathrm{X}_{1}+0,883065 \mathrm{X}_{3}+1,044302 \mathrm{X}_{5}+0,928253 \mathrm{X}_{7}+0,998604 \mathrm{X}_{9} \\
& \left(<2 \times 10^{-16}\right) \quad\left(<2 \times 10^{-16}\right) \quad\left(<2 \times 10^{-16}\right) \quad\left(<2 \times 10^{-16}\right) \quad\left(<2 \times 10^{-16}\right)
\end{aligned}
$$

Hasil prediksi MAR filter Haar dengan $j=4$ bila diplotkan dengan data asli akan tampak seperti Gambar 8:

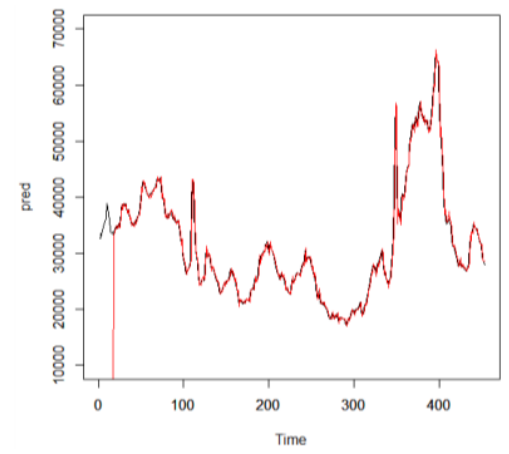

Gambar 8. Plot Time Series Data Asli dan Prediksi MAR Filter Haar dengan j = 4

Dari masing-masing model yang didapat, diketahui besaran MSE untuk tiap level ke $j$ pada filter Haar sebagai berikut:

Tabel 3. Nilai MSE Prediksi MAR filter Haar pada level ke j

\begin{tabular}{|cc|}
\hline Level Resolusi & Nilai MSE \\
\hline$j=1$ & 2239500 \\
$j=2$ & 2228796 \\
$j=3$ & 2226695 \\
$j=4$ & 2175906 \\
\hline
\end{tabular}

Berdasarkan nilai MSE pada tabel di atas, maka prediksi terbaik untuk filter Haar dihasilkan pada pendekatan level $(j) 4$ karena memiliki nilai MSE terkecil.

\subsubsection{Model Pendekatan dengan Filter Daubechies 4}

\section{a. Filter Daubechies 4 dengan $j=1$}

Model awal yang terbentuk dengan memasukan empat variabel adalah: 


$$
\begin{aligned}
& \hat{Z}_{t+1}=-1,43871 \mathrm{X}_{1}+0,21379 \mathrm{X}_{2}+1,14320 \mathrm{X}_{3}-0,14609 \mathrm{X}_{4} \\
& \left(<2 \times 10^{-16}\right) \quad(0,183) \quad\left(<2 \times 10^{-16}\right) \quad\left(1,88 \times 10^{-8}\right)
\end{aligned}
$$

Model yang terbentuk dari tiga variabel yang signifikan adalah

$\hat{Z}_{t+1}=-1.42834 \mathrm{X}_{1}+1.13569 \mathrm{X}_{3}-0.13854 \mathrm{X}_{4}$

$$
\left(<2 \times 10^{-16}\right) \quad\left(<2 \times 10^{-16}\right) \quad\left(4,52 \times 10^{-8}\right)
$$

Hasil prediksi MAR filter Daubechies 4 dengan $j=1$ bila diplotkan dengan data asli akan tampak seperti Gambar 9:

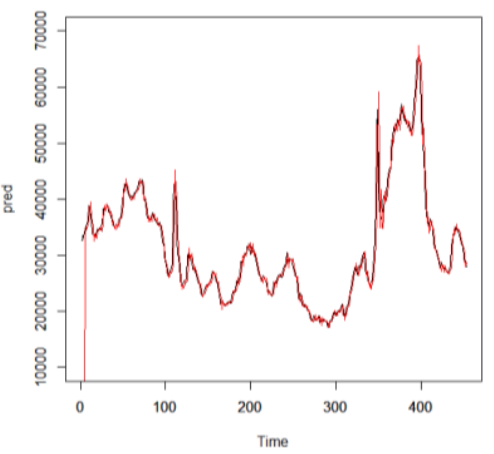

Gambar 9. Plot Time Series Data Asli dan Prediksi MAR Filter D4 dengan $\mathrm{j}=1$

b. Filter Daubechies 4 dengan $\boldsymbol{j}=\mathbf{2}$

Model awal yang terbentuk dengan memasukan enam variabel adalah:

$$
\begin{aligned}
\hat{Z}_{t+1}= & -1,78319 \mathrm{X}_{1}+0,40831 \mathrm{X}_{2}-1,55899 \mathrm{X}_{3}+0,41148 \mathrm{X}_{4} \\
& \left(5,15 \times 10^{-15}\right) \quad(0,0606) \quad\left(<2 \times 10^{-16}\right) \quad(0,0027) \\
& +1,07349 \mathrm{X}_{5}-0,07794 \mathrm{X}_{6} \\
& \left(<2 \times 10^{-16}\right) \quad(0,0006)
\end{aligned}
$$

Model yang terbentuk dari lima variabel yang signifikan adalah $\hat{Z}_{t+1}=-1,76508 \mathrm{X}_{1}-1,50356 \mathrm{X}_{3}+0,39944 \mathrm{X}_{4}+1,07153 \mathrm{X}_{5}-0,7600 \mathrm{X}_{6}$

$$
\begin{array}{lllll}
\left(1,03 \times 10^{-14}\right) & \left(<2 \times 10^{-16}\right) & (0,0037) \quad\left(<2 \times 10^{-16}\right) \quad(0,00077)
\end{array}
$$

Hasil prediksi MAR filter Daubechies 4 dengan $j=2$ bila diplotkan dengan data asli akan tampak seperti Gambar 10:

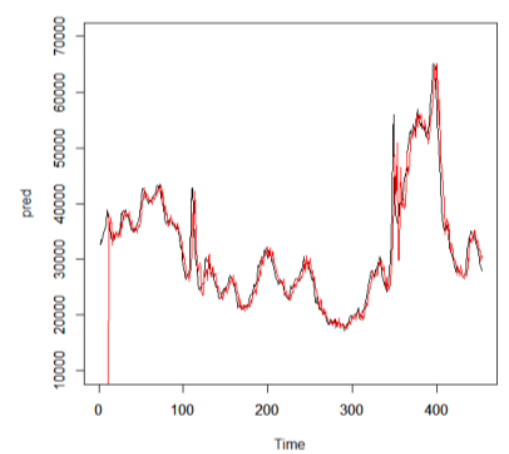

Gambar 10. Plot Time Series Data Asli dan Prediksi MAR Filter D4 dengan $j=2$

c. Filter Daubechies 4 dengan $j=3$

Model awal yang terbentuk dengan memasukan delapan variabel adalah:

$$
\begin{aligned}
& \hat{Z}_{t+1}=-1,22685 \mathrm{X}_{1}-0,61258 \mathrm{X}_{2}-1,80697 \mathrm{X}_{3}-0,33120 \mathrm{X}_{4} \\
& \left(4,18 \times 10^{-5}\right) \quad(0,0386) \quad\left(<2 \times 10^{-16}\right) \quad(0,104) \\
& -1,50296 X_{5}-0,16989 X_{6}+1,09946 X_{7}-0,10742 X_{8} \\
& \left(<2 \times 10^{-16}\right) \quad(0,1487) \quad\left(<2 \times 10^{-16}\right) \quad\left(8,23 \times 10^{-7}\right)
\end{aligned}
$$

Model yang terbentuk dari enam variabel yang signifikan adalah 


$$
\begin{aligned}
\hat{Z}_{t+1}= & -1,18930 \mathrm{X}_{1}-0,59102 \mathrm{X}_{2}-1,77841 \mathrm{X}_{3}-1,41676 \mathrm{X}_{5}+1,10339 \mathrm{X}_{7}-0,11150 \mathrm{X}_{8} \\
& \left(7,23 \times 10^{-5}\right) \quad(0,0464) \quad\left(<2 \times 10^{-16}\right)\left(<2 \times 10^{-16}\right) \quad\left(<2 \times 10^{-16}\right) \quad\left(2,77 \times 10^{-7}\right)
\end{aligned}
$$

Hasil prediksi MAR filter Daubechies dengan $j=3$ bila diplotkan dengan data asli akan tampak seperti Gambar 11:

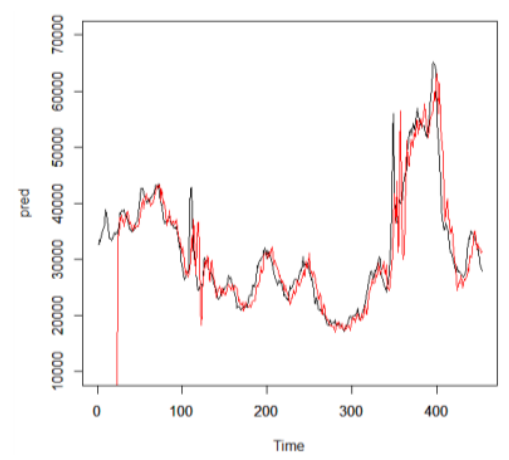

Gambar 11. Plot Time Series Data Asli dan Prediksi MAR Filter D4 dengan j $=3$

d. Filter Daubechies 4 dengan $\boldsymbol{j}=\mathbf{4}$

Model awal yang terbentuk dengan memasukan sepuluh variabel adalah:

$\hat{Z}_{t+1}=-0,85926 \mathrm{X}_{1}-0,42798 \mathrm{X}_{2}-1,08565 \mathrm{X}_{3}-2,12717 \mathrm{X}_{4}-2,44454 \mathrm{X}_{5}$

$$
(0,0224) \quad(0,2526) \quad\left(1,59 \times 10^{-5}\right)\left(3,62 \times 10^{-14}\right)\left(<2 \times 10^{-16}\right)
$$

$-1,31470 \mathrm{X}_{6}-1,68567 \mathrm{X}_{7}+0,23950 \mathrm{X}_{8}+1,11566 \mathrm{X}_{9}-0,13107 \mathrm{X}_{10}$

$\left(1,76 \times 10^{-12}\right)\left(<2 \times 10^{-16}\right) \quad(0,0977) \quad\left(<2 \times 10^{-16}\right) \quad\left(1,47 \times 10^{-10}\right)$

Model yang terbentuk dari delapan variabel yang signifikan adalah

$\hat{Z}_{t+1}=-0.87389 \mathrm{X}_{1}-1.13274 \mathrm{X}_{3}-2.12752 \mathrm{X}_{4}-2.46608 \mathrm{X}_{5}$

$(0,0205) \quad\left(5,14 \times 10^{-6}\right) \quad\left(3,33 \times 10^{-14}\right) \quad\left(<2 \times 10^{-16}\right)$

$-1.31900 \mathrm{X}_{6}-1.61735 \mathrm{X}_{7}+1.10992 \mathrm{X}_{9}-0.12515 \mathrm{X}_{10}$

$\left(1,69 \times 10^{-12}\right)\left(<2 \times 10^{-16}\right) \quad\left(<2 \times 10^{-16}\right) \quad\left(5,58 \times 10^{-10}\right)$

Hasil prediksi MAR filter Daubechies 4 dengan $j=4$ bila diplotkan dengan data asli akan tampak seperti Gambar 12:

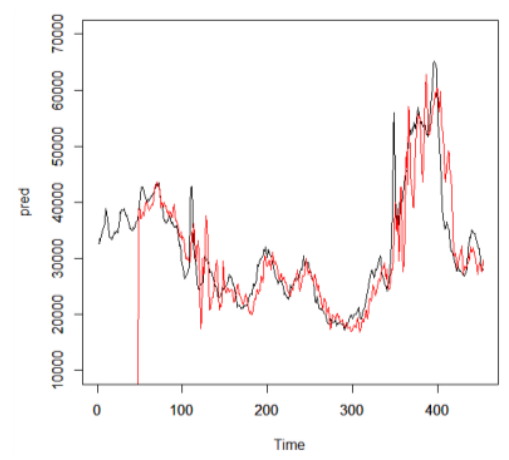

Gambar 12. Plot Time Series Data Asli dan Prediksi MAR Filter D4 dengan $j=4$

Dari masing-masing model yang didapat, diketahui besaran MSE untuk tiap level ke $j$ pada filter Daubechies 4 sebagai berikut:

Tabel 4. Nilai MSE Prediksi MAR filter Daubechies 4 pada level ke j

\begin{tabular}{|cc|}
\hline Level Resolusi & Nilai MSE \\
\hline $\mathrm{j}=1$ & 3999669 \\
$\mathrm{j}=2$ & 7080040 \\
$\mathrm{j}=3$ & 12530579 \\
$\mathrm{j}=4$ & 18541207 \\
\hline
\end{tabular}


Berdasarkan nilai MSE pada tabel di atas, maka prediksi terbaik untuk filter Daubechies 4 dihasilkan pada pendekatan level (j) 1 karena memiliki nilai MSE terkecil.

Dari hasil analisis model runtun waktu dengan pendekatan wavelet MODWT, dilakukan perbandingan nilai MSE model MAR antara filter Haar dan Daubechies 4 dengan level terpilih. Diketahui bahwa filter Haar dengan level (j) 4 memiliki nilai MSE yang lebih kecil daripada filter Daubechies 4 dengan level (j) 1. Maka, data harga cabai merah besar di Jawa Tengah dapat lebih baik diramal dengan pendekatan wavelet MODWT filter Haar. Hasil peramalan harga cabai merah besar di Jawa Tengah untuk 21 periode kedepan dengan menggunakan filter Haar dapat dilihat pada Tabel.

Tabel 5. Hasil Peramalan dengan Wavelet

\begin{tabular}{|lllll|}
\hline $\begin{array}{l}\text { Data } \\
\text { Testing }\end{array}$ & $\begin{array}{l}\text { Data Peramalan } \\
\text { Haar } j=1\end{array}$ & $\begin{array}{l}\text { Data } \\
\text { Peramalan } \\
\text { Haar } j=2\end{array}$ & $\begin{array}{l}\text { Data } \\
\text { Peramalan } \\
\text { Haar } j=3\end{array}$ & $\begin{array}{l}\text { Data } \\
\text { Peramalan } \\
\text { Haar } j=4\end{array}$ \\
\hline 28050 & 27696.52 & 27713.91 & 27729.94 & 27792.48 \\
26450 & 27561.73 & 27612.86 & 27645.46 & 27823.7 \\
25300 & 27465.34 & 27551.86 & 27599.41 & 27934.05 \\
25050 & 27381.63 & 27490.32 & 27552.67 & 28063.66 \\
25450 & 27301.6 & 27422.57 & 27496.16 & 28216.66 \\
26050 & 27222.44 & 27347.18 & 27436.17 & 28367.55 \\
26750 & 27142.49 & 27272.17 & 27373.35 & 28503.03 \\
26700 & 27057.82 & 27200.15 & 27308.7 & 28612.97 \\
26000 & 26974.3 & 27129.18 & 27244.57 & 28685.13 \\
25750 & 26894.09 & 27063.39 & 27179.53 & 28719.96 \\
25800 & 26815.04 & 26998.23 & 27113.54 & 28716.42 \\
25300 & 26740.78 & 26932.66 & 27046.7 & 28682.27 \\
24850 & 26667.14 & 26867.84 & 26980.48 & 28617.16 \\
24300 & 26593.04 & 26802.22 & 26913.43 & 28534.29 \\
24100 & 26519.71 & 26735.6 & 26846.97 & 28441.83 \\
23750 & 26445.59 & 26668.21 & 26780.49 & 28344.72 \\
23150 & 26370.61 & 26601.38 & 26710.88 & 28251.16 \\
23250 & 26294.86 & 26533.73 & 26640.61 & 28162.63 \\
23750 & 26219.68 & 26466.65 & 26567.13 & 28080.32 \\
23800 & 26143.7 & 26399.57 & 26494.12 & 28008.15 \\
23300 & 26068.29 & 26329.37 & 26419.86 & 27943.91 \\
\hline MSE & $\mathbf{3 9 2 9 3 3 4 . 1 8}$ & $\mathbf{4 6 4 2 5 8 0 . 4 8}$ & $\mathbf{5 0 2 4 8 2 0 . 7 9}$ & $\mathbf{1 2 0 9 3 9 6 0 . 3 1}$ \\
\hline
\end{tabular}

Berdasarkan nilai MSE di atas, maka diperoleh hasil pendekatan ramalan model MAR filter Haar dengan level (j) 1 memiliki nilai terkecil yaitu sebesar 3929334,18.

\section{KESIMPULAN}

Berdasarkan analisis dan pembahasan yang telah dilakukan, dapat diperoleh beberapa kesimpulan bahwa proses analisis data harga cabai merah besar di Jawa Tengah dengan menggunakan metode ARIMA kurang tepat jika dilakukan peramalan. Metode wavelet Maximal Overlap Discrete Wavelet Transform (MODWT) dapat digunakan sebagai alternatif penyelesaian analisis ARIMA. Penyelesaian dilakukan melalui dekomposisi pada MODWT 
dengan menggunakan filter Haar dan Daubechies 4 dengan level $(j)=1,2,3,4$ dan $A_{j}=2$, sehingga membentuk model MAR.

Model MAR yang terbentuk dari level $(j)=1,2,3,4$ diuji parameternya agar didapatkan parameter yang signifikan dengan model, kemudian mencari model terbaik dengan melihat MSE terkecil pada tiap model. Didapat hasil model terbaik untuk filter Haar adalah pada level (j) 4, yaitu

$\hat{Z}_{t+1}=1,752498 \mathrm{X}_{1}+0,883065 \mathrm{X}_{3}+1,044302 \mathrm{X}_{5}+0,928253 \mathrm{X}_{7}+0,998604 \mathrm{X}_{9}$

Sedangkan untuk filter Daubechies 4 model terbaiknya adalah pada level $(j)$, yaitu $\hat{Z}_{t+1}=-1.42834 \mathrm{X}_{1}+1.13569 \mathrm{X}_{3}-0.13854 \mathrm{X}_{4}$.

Perbandingan nilai MSE pada model MAR filter Haar dan model MAR filter Daubechies 4, menunjukkan bahwa model yang terbaik adalah pada wavelet MODWT filter Haar, karena memiliki nilai MSE terkecil. Selanjutnya, model MAR filter Haar digunakan untuk peramalan model. Diketahui hasil pendekatan ramalan model MAR filter Haar dengan level $(j) 1$ pada harga cabai merah besar di Jawa Tengah lebih baik daripada level lainnya.

\section{DAFTAR PUSTAKA}

[1] Eriawati. 2015. Pemanfaatan Jenis Tumbuhan dari Famili Solanaceae sebagai Media Pembelajaran Biologi pada Sub Konsep Klasifikasi Tumbuhan di SMP Negeri 1 Simpang Tiga Kabupaten Aceh Besar. Prosiding Seminar Nasional Biotik. Aceh.

[2] Hasan, I. 2002. Pokok-Pokok Materi Statistik 2 (Statistik Inferentif). Jakarta: Bumi Aksara.

[3] Kurnia, M. T., Nugrahani, E. H., \& Sumarno, H. 2014. Analisis Wavelet dan ARIMA untuk Peramalan Harga Emas PT. ANTAM Tbk. Indonesia. Jurnal Matematika, 13, 11-22.

[4] Lestari, V. N., \& Subanar. 2015. Transformasi Wavelet Diskrit untuk Data Time Series. Seminar Nasional Matematika dan Pendidikan Matematika UNY 2015, (hal. 163-170). Yogyakarta.

[5] Makridakis, S., Wheelwright, S. C., \& McGee, V. E. 1995. Metode dan Aplikasi Peramalan (Edisi kedua ed.). (U. S. Andriyanto, \& A. Basith, Penerj.) Jakarta: Erlangga.

[6] Percival, D. B., \& Walden, A. T. 2002. Wavelet Methods for Time Series Analysis. Cambridge, United Kingdom: Cambridge University Press.

[7] Pusat Informasi Harga Pangan Strategis (PIHPS) Nasional. 2018. Tabel Harga Berdasarkan Daerah. Retrieved from https://hargapangan.id

[8] Ranutinoyo, S. 2015. Produksi dan Konsumsi Cabai : Kebutuhan dan Peluangnya. Kompasiana.

[9] Renaud, O., Starck, J. L., \& Murtagh, F. 2002. Wavelet-based Forecasting of Short and Long Memory Time Series. Jenewa.

[10] Rosadi, D. 2012. Ekonometrika \& Analisis Runtun Waktu Terapan dengan E-views. Yogyakarta: CV. Andi Offset.

[11] Setiawan, R. 2018, Agustus 21. detikFinance. Dipetik Juli 2019, dari https://m.detik.com/finance/berita-ekonomi-bisnis/d-4175863/genjot-produksi-cabai-dijateng-kementan-beri-bantuan-rp-684-m

[12] Soejoeti, Z. 1987. Analisis Runtun Waktu. Jakarta: Karunika.

[13] Warsito, B., Subanar, \& Abdurakhman. 2013. Pemodelan Time Series dengan Maximal Overlap Discrete Wavelet Transform. Prosiding Seminar Nasional Statistika (hal. 605-613). Semarang: Universitas Diponegoro.

[14] Wei, W. W. 2006. Time Series Analysis : Univariate and Multivariate Methods Second Edition. Boston: Addison Wesley Publishing Company.

[15] Yanuarti, A. R., \& Afsari, M. D. 2016. Profil Komoditas Cabai. Jakarta. 